\title{
The Effect of Perceived Corruption on Entrepreneurial Intention: Evidence from Italy
}

\author{
Alessandra Allini ${ }^{1}$, Luca Ferri ${ }^{1}$, Marco Maffei ${ }^{1}$, Annamaria Zampella ${ }^{1}$ \\ ${ }^{1}$ Department of Economics, Management, Institutions, University of Naples Federico II, Italy \\ Correspondence: Luca Ferri, Department of Economics, Management, Institutions, University of Naples \\ Federico II, Italy.
}

Received: March 29, 2017

Accepted: May 5, $2017 \quad$ Online Published: May 13, 2017

doi:10.5539/ibr.v10n6p75

URL: https://doi.org/10.5539/ibr.v10n6p75

\begin{abstract}
This paper aims to examine the entrepreneurial intention of undergraduate students, using a modified version of Ajzen's theory of planned behavior (TPB), considering the perception of corruption. We conducted a questionnaire survey with Italian students. There were a total of 350 student participants. In order to analyze the data collected with the questionnaire, structural equation modeling is provided. Our results indicate that the majority of students have strong entrepreneurial intention but due to the effect of corruption students are dissuaded from engaging in entrepreneurship. Corruption has a negative effect on students' entrepreneurial behavior. This paper provides a new model that helps to understand the students' entrepreneurial intentions considering the corruption perception.
\end{abstract}

Keywords: corruption, theory of planned behavior, entrepreneurial intention

\section{Introduction}

Entrepreneurship is a complicated, risky and uncertain process; for this reason not everyone is able to start a new business (Fatoki, 2010). The entrepreneurial process is experimental by nature (Fatoki, 2010) but it is plausible that entrepreneurial intentions are influenced by past experiences (Robinson et al., 1991; Sullivan, 2000; Minniti \& Bygrave, 2003; Politis, 2005), personal formation (Harris \& Gibson, 2008; Hussain et al., 2008) and personal attitudes (Robinson et al., 1991; Hatten \& Ruhland, 1995; Krueger et al., 2000). For example, according to Robinson et al. (1991) and Hatten \& Ruhland (1995), attitudes and intentions about entrepreneurship can be learned, measured and improved. Se veral authors stated that entrepreneurial skills can be learned (Kuratko, 2005; Stuetzer et al., 2013) as is demonstrated by the growing number of entrepreneurship programs at universities (Kuratko, 2005; Matlay, 2006). Further literature focused on entrepreneurial intention to examine the key determinants (Krueger et al., 2000) in the decision making process of young entrepreneurs (Baum et al., 2014; Omorede et al. 2015). This literature explains the main motivations of entrepreneurial intention but does not consider the existing limitations to would-be entrepreneurs actually starting up businesses (Shin, 2015; Lund, 2016). While there are several studies that explain how people take the decision to become entrepreneurs, there is a lack of literature about the factors that prevent people from engaging in entrepreneurial activity.

The existing body of literature does not consider the external factors that could reduce the intention to start a new venture. Far less attention has been focused on these factors, known as "entrepreneurial inhibitors", considered as all the factors that could represent a limitation to entrepreneurial intentions. According to Estrin et al. $(2006$; 2013) one of the main entrepreneurial inhibitors is the perception of corruption. Shin (2015) discusses this statement, highlighting that high levels of corruption can reduce the degree of competitiveness due to the "unfair-play". More specifically, high levels of perceived corruption can deter people from becoming entrepreneurs in order to avoid the risk of wasted effort. This phenomenon presents an important problem; corruption can significantly reduce entrepreneurial intention thereby economically weakening a state or region and reducing the possibility of work for students. A complete understanding of the constraints produced by entrepreneurial inhibitors is crucial to researchers and practitioners if they are to counteract the negative impact on the behavior and choices of potential entrepreneurs.

The purpose of the present study is to examine the effect of perceived corruption, considered as the main entrepreneurial inhibitor (Shin, 2015), on students' entrepreneurial intentions and behavior. To this aim we used a modified version of Ajzen's Theory of planned behavior (TPB) (Ajzen, 1985) integrated with perceived 
corruption. We choose the theory of planned behavior because its predictive force is widely recognized in previous research (Fayolle \& Liñán, 2014; Kautonen et al., 2011, 2015).

The paper is organized as follows: Section 2 provides a review of the literature about entrepreneurial intention, corruption and theory of planned behavior. Section 3 describes the methodology used for our research. Section 4 presents the research results and the discussion. Finally, Section 5 provides the conclusions.

\section{Literature Review}

\subsection{Entrepreneurial Intention}

There are numerous definitions ascribed to the term "entrepreneurship" (Covin \& Slevin, 1991; Bruyat \& Julien, 2001), ranging from the specific, starting one's own business, to the abstract, a work attitude that emphasizes self-reliance, initiative, innovati veness, and risk-taking (Gartner, 1990; Montano \& Kasprzyk, 2015). Nowadays, shifts in the socio-economic landscape have left fewer opportunities for continuous employment. This has caused a radical change in individual work preferences, with many now favoring self-reliant employment options (Baruch, 2004; Gibb, 2002; Hall, 2002). Further literature about entrepreneurial intention has focused on issues such as social contexts (Martin \& Osberg, 2007; Abu-Saifan, 2012), personality traits (Zhao \& Seibert, 2006; Aranha et al., 2017) and personal experiences (Zhao et al., 2005) to explain the reasoning behind and individual's intention to become an entrepreneur (Dyer, 1994; Henderson \& Robertson, 1999; Henry et al., 2005; Gozukara \& Colakoglu, 2015). Moreover, much of the research that seeks to explain entrepreneurial intentions (EI) is flawed (Mitchell et al., 2007). Many researchers have focused on the prediction of entrepreneurial intentions (EI) rather than on the realization. For example, Zhao et al. (2005) found that entrepreneurial intentions are strongly related to personal attitude and to self-perception.

\subsection{Corruption Perception}

According to Everett et al. (2007), the main entrepreneurial inhibitor is the perception of corruption. We currently live amidst a "corruption eruption" (Glynn et al., 1997; Everett et al., 2007); several authors claim that this is a moment of crisis that could have many pernicious consequences (Fjeldstad \& Tungodden, 2003) such as loss of government revenue (Stapenhurst \& Sedigh, 1999; Fjeldstad \& Tungodden, 2003; Everett et al., 2007), costs for businesses that engage in corruption and missed opportunities for those that do not (Caiden et al., 2001) Corruption represents a distortion in standards of merit that reduce the respect for law, resulting in higher investment for public sector and firms, and a lower quality of services (Hamir, 1999; Everett et al. 2007). This definition was used also by Estrin et al. (2013), which stated that corruption is an informal institution negatively associated with economic variables such as gross domestic product per capita (GDP) (Kaufman and Kraay, 2006; Estrin et al, 2013; Quazi et al., 2014), income equality (Carmignani, 2005) and total factor productivity (Lambsdorff, 2003). What should be noted is that, despite these different definitions, there is an overwhelming consensus in the literature of the disruptive power that corruption has over economic systems. According to Melgar et al. (2010), corruption perception is cultural phenomena that depends on a deviation from the social understanding of the rules. Indeed, it depends on personal and moral values and reflects the propensity of people to pay in order to receive something illegal. Corruption does not directly reflect the degree of perceived corruption. High levels of corruption perception could have more devastating effects than corruption itself, generating a social phenomenon known as "culture of distrust" (Melgar et al., 2010). In this situation corruption perception can create "demotivation" in doing something between people. This demotivation can be translated to market inequality (Gupta et al., 2002) and thus lower entrepreneurial intentions. This idea was shared by Azmat and Samaratunge (2004) according whom corruption represents the most corrosive bottleneck afflicting economic and social growth worldwide. Griffiths et al. (2009) demonstrate that corruption considerably reduces the interest and desirability to start a new business activity. Many other authors have highlighted the problems created by corruption in different counties; acts of fraud (Cohen et al., 2010; Chwastiak, 2013), health and safety violations (Radin \& Calkins, 2006), and tax evasion (Everett et al., 2007; Otusanya, 2011) are just few examples of activities that privilege self-interests over social ones. Corruption is an environmental factor that should have negative effect on people's actions. In this research we will focus on the effects of corruption perception on the students motivation to be entrepreneurs.

\subsection{Theory of Planned Behavior and Hypothesis Development}

Literature about entrepreneurial intent has been studied mainly using two models: the model of the entrepreneurial event (SEE) (Shapero \& Sokol, 1982) and the theory of planned behavior (TPB) (Ajzen, 1985). The SEE focuses on the individual by including a measure of proactiveness whereas the TPB focuses on the environment by detailing the social setting to contextualize the behavior. For this reason TPB is widely used in literature about entrepreneurial intentions. Several studies used this model because it considers the effects of 
social and other external variables on individual behavior. The theory of planned behavior argues that there are three precursors (constructs) to intentions, intentions being the antecedent to behavior (Ajzen, 1985). The precursors are: personal attitude toward the behavior, perceived social norms, and perceived behavioral control. The first and the second reflect the perceived desirability of performing the behavior, while the third reflects perceptions that the behavior is personally controllable. Perceived behavioral control reflects the perceived feasibility of performing the behavior and is thus related to perceptions of situational competence (self-efficacy). TPB details the precursors of each of these attitudes. Indeed, attitude has a behavioral component (i.e. affective and cognitive components) that consists of predispositions to behave in a particular manner (Shaver, 1987). In order to provide a complete view of the theory of planned behavior we provide figure 1.

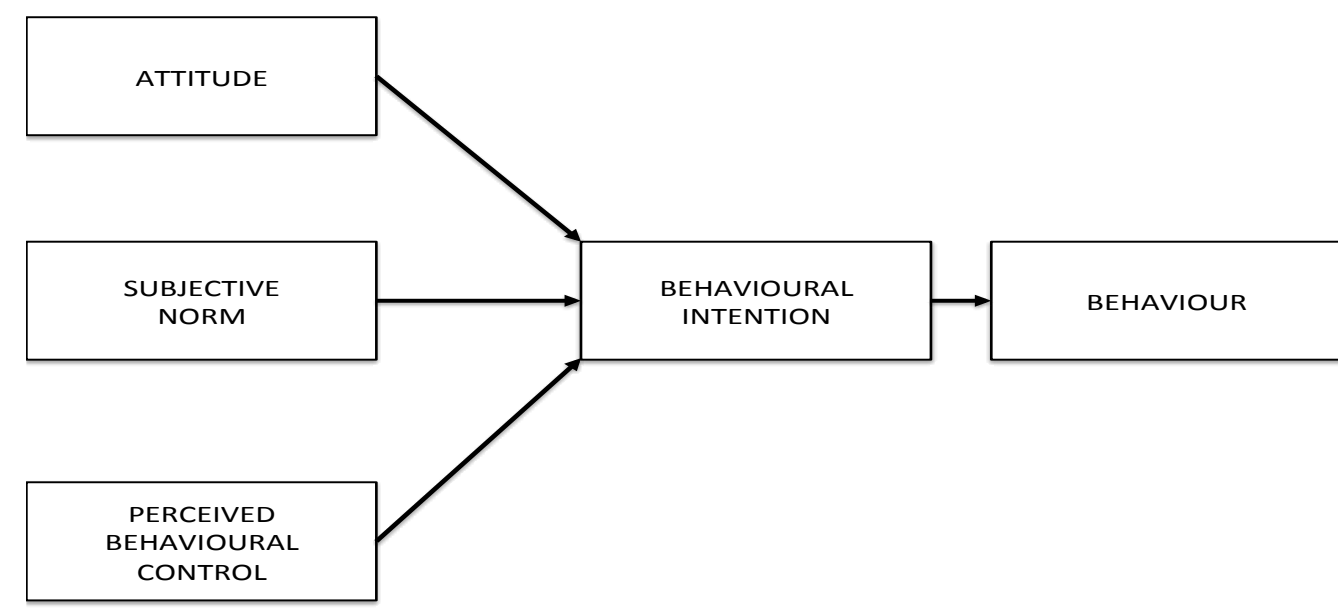

Figure 1. Ajzen's Theory of planned behavior (1985)

With reference to the attitude, this construct shows the perceptions of the personal desirability of performing the behavior (Zhao et al., 2005). Attitude depends on individual expectations and beliefs about the outcomes of the behavior. This construct allows us to measure the expectations of people in the sample about theirs ability in doing something (Shapero \& Sokol, 1982). More specifically, it is referred to the degree to which a person has a favorable evaluation of the behavior in question (Ajzen, 1985). Individuals form attitudes about a particular behavior by associating the behavior with the likely outcome that will result. If the outcomes are largely desirable, there will be a stronger intention to perform the behavior. In the case of entrepreneurial intention, attitude toward the behavior can be considered as the desirability of creating a new firm. In the entrepreneurial context, a positive perception of expected outcomes is typically associated with the act of starting one's own business (Shapero \& Sokol, 1982; Zhao et al. 2005; Shook \& Bratianu, 2010; Montano \& Kasprzyk, 2015; Di Paola et al., 2016). Based on cited authors, the following hypothesis can be advanced:

\section{$H_{1}$ : The attitude toward the behavior is positively related to entrepreneurial intention.}

With reference to the perceived social norms (or normative beliefs), this construct allows to understand the importance of the perceptions of performing a particular behavior (Ajzen, 1985). For example, consider the family expectations about the desirability of becoming a doctor, an accountant or an entrepreneur. However, these normative beliefs also depend on the strength of the motivation to comply with them (Ajzen, 1985). Subjective norms can have different effect on behavioral intention. The research findings about the effect of subjective norms on entrepreneurial intent have been mixed. Krueger et al. (2000) found that the effect of social support is not related to entrepreneurial intent in for North-American students. Autio \& Arcs (2001) and Liñán \& Chen (2009) carried out a comparative study and also found that social support is weakly correlated with entrepreneurial intent in American students however the opposite is true for Scandinavian students. It should be noted that in contexts with more uncertainty, social support should be an important factor with a significant effect on entrepreneurial intent. It can be stated that students with higher support have more possibility to become entrepreneur. On the basis of further literature, we can state the following hypothesis:

\section{$\mathrm{H}_{2}$ : Subjective norm is positively related to entrepreneurial intention.}

Perceived behavioral control (PBC) indicates the perceived self-efficacy of the individual or the individual's 
perceived ability to execute a goal behavior (i.e. to became entrepreneur) (Ajzen, 1985). Self-efficacy is linked to initiating and persisting with the behavior under uncertainty, to setting higher goals, and to reducing threat-rigidity and learned helplessness (Bandura 1986). This construct is important because situational controllability is strongly related to self-perception (Dutton \& Ashford, 1993; Krueger \& Braezeal, 1994; Harackiewicz et al., 2002; Kolvereid \& Isaksen, 2006) and to self-efficacy (Krueger \& Dickson, 1994). Entrepreneurship researchers largely ignore the concept of self-efficacy despite its importance in predicting specific behaviors (Strecher et al., 1986; Harackiewicz et al., 2002). Self-efficacy has been associated with opportunity recognition and risk-taking (Krueger \& Dickson, 1994; Krueger et al., 2000; Di Paola et al., 2016) as well as career choice (Bandura, 1986; Harackiewicz et al., 2002; Turker \& Selcuk, 2009). On the basis of further literature, we can state the following hypothesis:

\section{$H_{3}$ : Perceived behavioural control is positively related to entrepreneurial intention.}

We integrated TPB with perceived corruption. As stated by other authors (Griffiths et al, 2009) perceived corruption is an external factor that can restrict entrepreneurial activity. Corruption is not only a social pathology but also an economic and political problem (Sevuktekin et al., 2010; Spanò et al., 2016). It includes all activities that abuse public positions for personal use and all situations in which the personal interest prevails over the public one. It can occur in different sectors such as economic (trade policy and privatization), legal (rule of law, independence of judiciary), bureaucratic, administrative and transnational factors, civil liberties, and press freedoms (Li \& Bray, 2007; Sevuktekin et al. 2010; Spanò et al., 2017). A strong perception of corruption can create demotivation and cause people to be reluctant about becoming entrepreneurs. People with strong personal values could decide to avoid the problems arising from corrupted systems by choosing to not be self-employed or entrepreneurs.

In Italy, corruption is perceived as a prevalent phenomenon (D’Onza et al. 2016; Spanò et al., 2016; Spanò et al., 2017). Corruption is considered as a major problem in the public sector with certain business activities slowing down the economic growth. The high degree of corruption in Italy is strongly perceived across Europe; the 2014 Transparency International Survey ranked Italy as 69 out of 177 for the degree of perceived corruption. This data has great importance because a high perception of corruption can inhibited entrepreneurial activity (Shin, 2015). According to the author, high le vels of corruption means that the playing field is not even therefore it is difficult for firms to reach success and more difficult for new entrepreneurs to establish their ventures so they can decide to not start a new venture at all. According to this statement we can state the following hypotheses:

\section{$H_{\cdot 4}$ Corruption perception has a strong negative effect on students 'intention to be entrepreneurs}

$H_{.5}$ Corruption perception has a strong negative effect on students'entrepreneurial behavior

The following image shows our model that integrates the theory of planned behavior integrated with perceived corruption.

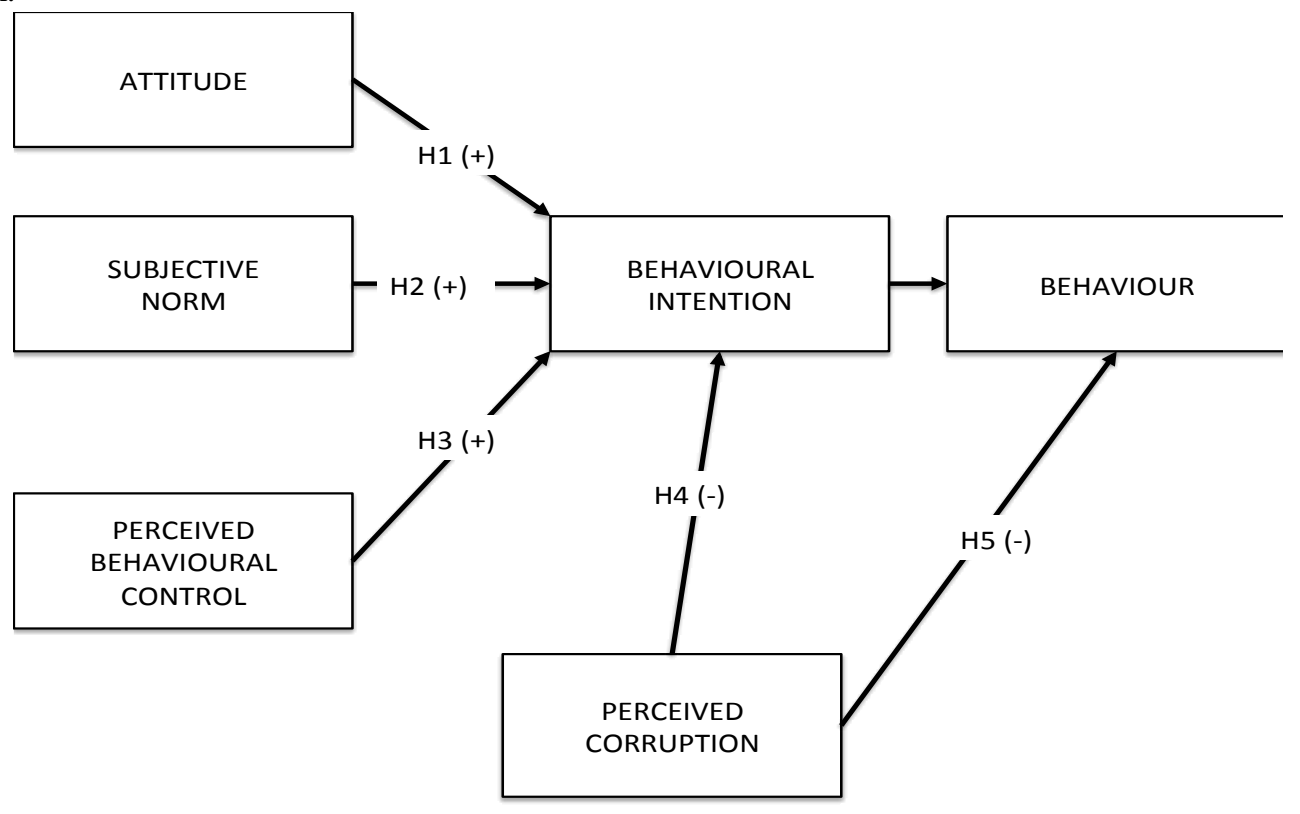

Figure 2. Theory of Planned behavior integrated with corruption perception 


\section{Methodology}

\subsection{The Questionnaire}

Using the Ajzen's TPB (1985) as a base, we carried out a questionnaire survey in order to understand the students' intentions to be entrepreneurs considering their perceptions of corruption. The questionnaire was divided into three parts. The first part contained the personal data of the students interviewed. The second part covered the TPB dimensions using 42 different questions: 10 questions for attitude, 10 for subjective norm, 10 for perceived behavioral control, nine for behavioral intentions, and three for behavior. The third part covered the corruption perception between students with three questions. All the questions were quantified using a four-point Likert Scale set from four (strongly agree) to one (strongly disagree). The questionnaire was designed taking into account Ajzen's (1985) approach. We employed an even scale in order to avoid the risk of central bias (Caldarelli et al., 2016). After this design phase, we disseminated the questionnaire to an initial sample of 45 subjects in order to test the scale.

\subsection{Scale Validation}

To ensure consistency and unidimensionality of the scales, we used the same approach as Gangwar et al. (2014). First of all, we carried out an initial reliability study and an exploratory factor analysis of principal components (PCA) (Hu \& Bentler, 1995, 1998, 1999; Byrne, 2013; Brown, 2015). This procedure was used to suppress indicators with a correlation lower than 0.3, or whose exclusion increased the Cronbach's Alpha value, which should not be lower than 0.7 (Bland and Altman, 1997). On this basis, we eliminated two factors of SN and one factor of PBC. No other factors were eliminated. Our tests show alpha values of 0.924 for ATT, 0.87 for SN, 0.898 for PBC and 0.861 for CORR. BI and BEHA got acceptable alpha values (0.88 and 0.832). Furthermore, we carried out an exploratory factor analysis using varimax rotation with Kaiser normalization (Kaiser, 1970; McDonald, 1981; Byrd, 2000) in order to verify if all the concepts were formed by just one factor. These factors explain more than $55 \%$ of the variance for all factors and it is valuable acceptable.

\subsection{Questionnaire Dissemination and Final Sample}

After the validation step, the survey was manually disseminated to a sample of 400 business students covering three different Italian universities. We chose business students because of their attitude to be entrepreneurs (Harris \& Gibson, 2008). Sample groups were randomly selected during lessons. We disseminated the survey manually in order to avoid the difficulties of obtaining replies associated with other means of communication (I.e.: email, social media, etc.) (Min \& Galle, 2003). The dissemination phase lasted for two months. After removing the incomplete forms, we reached a final sample of 350 students with a response rate of $87.5 \%$.

\section{Results and Discussion}

The current study used Warp PLS and Stata to analyze the data. Following Anderson \& Gerbing (1988), we carried out a Confirmatory Factor Analysis (CFA) for the assessment of the model adequacy and used Structural Equation Modeling (SEM) to test causal relationships (Hair et al., 1998).

We assessed model goodness-of-fit and quality indices. We carried out the chi-square. This test is widely used to assesses the adequacy of a model; the test results indicate the ability of the model to reflect variance and covariance of the data (Byrne, 2013; Hosmer et al. 2013). To avoid the bias of "sample size" we carried out other fit indices such as goodness of fit index (GFI), adjusted goodness-of-fit index (AGFI), comparative fit index (CFI), normed fit index (NFI), relative fit index (RFI), average block VIF (AVIF), average full collinearity VIF (AFVIF), average path coefficient (APC) and average adjusted R-square. The results of structural equation modeling obtained for the proposed conceptual model revealed a ratio of chi-square of 557 with $\mathrm{p}<0.001$.

We obtained the following results: a goodness-of-fit index (GFI) of 0.91 (ideal $>0.90$ ), adjusted goodness-of-fit index (AGFI) of 0.83 (considered good if $>0,8$ ), comparative fit index (CFI) of 0.93 (ideal if $>0,9$ ), normed fit index (NFI) of 0.91 (ideal if $>0,9$ ), relative fit index (RFI) of 0.90 (ideal if $>0.9$ ) and, finally, root mean square error of approximation (RMSEA) of 0.05 (ideal < 0.08). We also carried out the average block VIF (AVIF) obtaining a result of 1.567 (considered acceptable if $<=5$, ideally $<=3.3$ ), the average full collinearity VIF (AFVIF) was 2.012 (acceptable with values less or equal to 5, ideally $<=3.3$ ). Finally we have a R-squared contribution ratio (RSCR) of 1.000 (acceptable if $>=0.9$, ideally $=1$ ). The index of fit indicates a good model fit (Bagozzi et al., 1991; Hair and et al., 1998, 1999; Henseler et al., 2015) suggesting that the overall model fit is acceptable.

In order to understand the model prediction capacity, we carried a measure of average adjusted R-squared (AARS). It was of 0.454 (with $\mathrm{p}<0.001$ ) meaning that the variables used explain $45.4 \%$ of the total variance or entrepreneurial intention. After the test of the goodness of fit, we carried out a structural equation modeling 
(SEM) (Bagozzi et al., 1991). The following figure (Figure 3) and table (Table 2) show the results of the structural equation model and the findings in light of the formulated hypothesis.

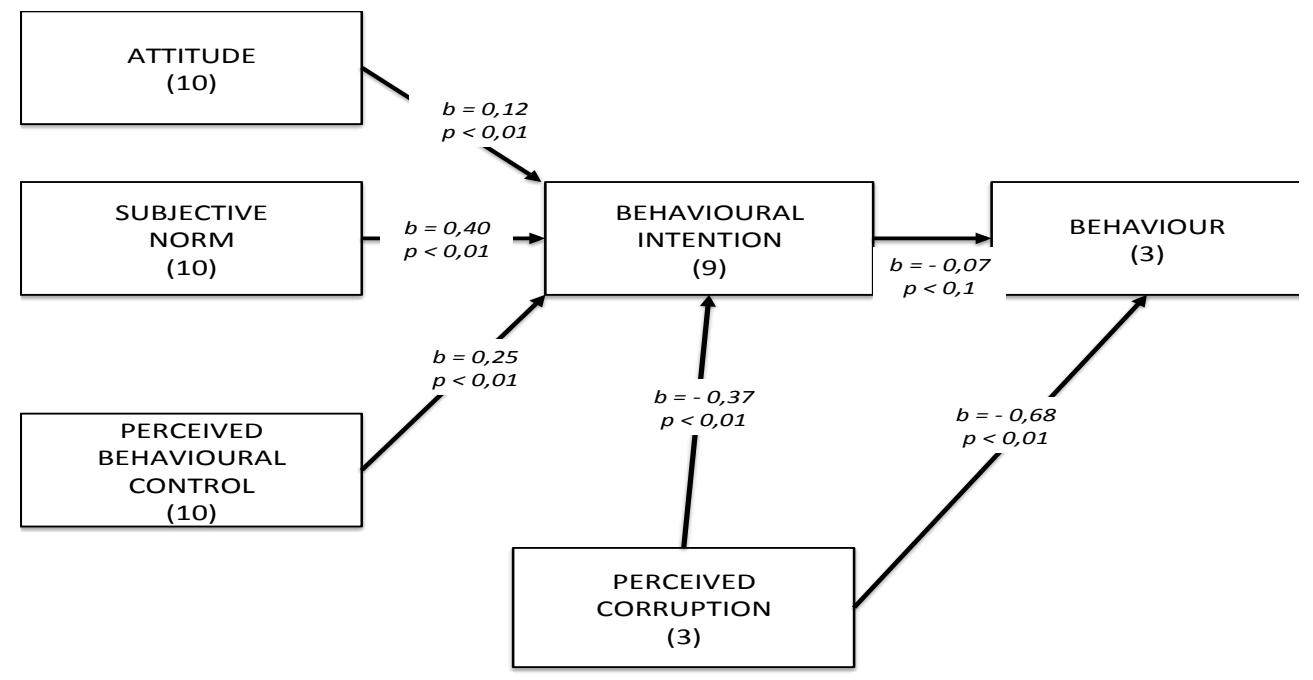

Figure 3. Results of structural equation model

Table 2. Research results

\begin{tabular}{|c|c|c|c|}
\hline No. & Hypothesis & Path Coefficient & Findings \\
\hline H1 & $\begin{array}{l}\text { The attitude toward the behavior is positively related } \\
\text { to entrepreneurial intention. }\end{array}$ & 0.12 & $\begin{array}{l}\text { Supported } \\
p<0.01\end{array}$ \\
\hline H2 & $\begin{array}{l}\text { Subjective norm is positively related to } \\
\text { entrepreneurial intention. }\end{array}$ & 0.40 & $\begin{array}{l}\text { Supported } \\
p<0.01\end{array}$ \\
\hline H3 & $\begin{array}{l}\text { Perceived behavioral control is positively related to } \\
\text { entrepreneurial intention. }\end{array}$ & 0.25 & $\begin{array}{l}\text { Supported } \\
p<0.01\end{array}$ \\
\hline H4 & $\begin{array}{l}\text { Corruption perception has a strong negative effect on } \\
\text { students intention to be entrepreneurs }\end{array}$ & -0.37 & $\begin{array}{l}\text { Supported } \\
p<0.01\end{array}$ \\
\hline H5 & $\begin{array}{l}\text { Corruption perception has a strong negative effect on } \\
\text { students entrepreneurial behavior }\end{array}$ & -0.68 & $\begin{array}{l}\text { Supported } \\
p<0.01\end{array}$ \\
\hline
\end{tabular}

Attitude (ATT) has a low positive effect on entrepreneurial intentions (EI) $(b=0.12$ with $p<0.01)$. This means that the personal perception to perform the behavior does not have a strong effect on students' intentions to become entrepreneurs. Our results concur with Davidsson (1995), but disagree with Douglas \& Shepherd (2002). Phan et al. (2002) found that ATT should be the stronger predictor of interest in self-employment and entrepreneurship. Despite a weak correlation between ATT and (EI), there is a strong entrepreneurial intention in Italian students. Other studies show a low path coefficient for ATT that it is considered as a poor predictor. The main reason for this is that attitude includes the students' preference for self-employment so, in a difficult context, they may prefer to make their own luck and become self-employed (Van Gelderen et al., 2008). Thus, hypothesis 1 is fully supported.

With reference to subjective norm ( $\mathrm{SN}$ ), our results show a strong and statistically significant relationship with entrepreneurial intentions $(b=0.40$ with $p<0.01)$. SN is the main factor that indicates the students' intentions to be entrepreneurs. These results are not in agreement with the conclusions drawn by Turker \& Selcuk (2009), according which social support does not have a great impact on entrepreneurial intentions and behavior. A possible explanation of these divergent results is that in Italy there is a lot of social pressure exercised by the people that students consider to be important in their lives, perhaps more so that many other countries. Our findings reveal that Italian students place great importance on the perceptions of what the people close to them (i.e. their families) think about engaging in entrepreneurial activity. Italian students could decide to be entrepreneurs if they perceived strong social support. This happens because students can have the "fear of failure" which can be partially mitigated by the support of the social group. Therefore, hypothesis 2 is supported. 
We found that perceived behavioral control (PBC) has a positive relationship with entrepreneurial intentions $(b=$ 0.25 with $p>0.01)$. According to these results the students have a good degree of the perceived ability to reach a pre-set goal. More specifically, Italian students have a good perception of their self-efficacy and, in their own opinions; they have the capacity to be entrepreneurs. Other empirical evidence (Bagozzi \& Kimmel, 1995; Armitage \& Conner, 2001) demonstrates that the PBC is closely associated with commitment measures, such as behavioral expectations. Hypothesis 3 is supported.

Finally, with reference to perceived corruption (CORR) our results show the existence of a strong and statistically relevant relation with behavioral intention $(\mathrm{BI})(\mathrm{b}=-0.37$ with $\mathrm{p}<0.01)$ and with behavior (BEHA) $(\mathrm{b}=-0,68$ with $\mathrm{p}<0,01$ ). These results reinforce the position of Melgar et al. (2010) and Enstrin et al. (2013) that corruption can be an inhibitor to entrepreneurial intention. Also, our results agree with the general idea according whom Italian students are limited in their work choices by "external variables". Indeed, our results show that the perceived level of corruption significantly reduces the behavioral intention so it is possible to state that cor ruption damages significantly the entrepreneurial activity of a region (Spanò et al., 2017). Also, it is possible to state that with a higher level of corruption perception there is a lower intention to become an entrepreneur. This statement is compliant with the findings of Azmat and Samaratunge (2004) and Cohen et al. (2010). As result, hypotheses 4 and 5 are fully supported.

\section{Conclusions}

This study investigates the effect of the perception of corruption on students' intentions to become entrepreneurs. While there are several studies that examined the determinants of entrepreneurial intentions there is a lack of research focusing on the relationship between entrepreneurial intentions and the entrepreneurial inhibitors. In this study we aim to fill this gap, using the theory of planned behavior integrated with corruption perception. We test the model on a sample of 350 Italian students.

Our results demonstrate that the perceived level of corruption has a negative effect on entrepreneurial intentions, significantly reducing entrepreneurial behavior. This means that, in the Italian context, the perception of corruption significantly reduces students' intention to be entrepreneurs (or self-employed). Furthermore, our results show that subjective norm is the main factor contributing to Italian students' entrepreneurial intentions. Also, our results show that subjective norms $(\mathrm{SN})$ and perceived behavioral control $(\mathrm{PBC})$ are significant predictors of individual motivations to engage in entrepreneurial activity. These results concur with previous scholarly research and also contribute further knowledge about entrepreneurial inhibitors. We found a significant drop in entrepreneurial intention upon introducing the perceived corruption. These results indicate that students are not interested in entrepreneurial careers while the degree of perceived corruption is high. A possible explanation of this phenomenon is that, despite the existence of strong social support, Italian students are not interested in starting a new venture if they know that there is an unfair play due to the existence of a strong corruption.

This study has several implications for regulators and researchers.

For regulators, the results of this study can shed light on some important issues related to entrepreneurial intentions in Italy. On one hand, we show that SN and PBC have a significant influence on behavioral intentions (BI), revealing a good personal propensity of students to be entrepreneurs. However, on the other hand our findings show that perception of corruption causes a drop in students' entrepreneurial behavior. This finding is particularly important for regulators because it highlights the need to take action towards reducing the level of corruption to support economic development through the start-up of new businesses.

For researchers, this study attempts to introduce a new variable in the theory of planned behavior (Ajzen, 1985). Hence, the proposed model makes an important contribution to the literature on entrepreneurial intention by adding entrepreneurial inhibitors as a new variable to the existing model. Furthermore, this study provides initial evidence to develop a deeper understanding of the causal relationship between entrepreneurial intentions and inhibitors.

This study has two main limitations. Firstly, although behavioral intention is the most important predictor of intention (Armitage \& Conner, 2001; Ajzen, 1991; Ajzen \& Fishbein, 1980), this intention does not always translate to actual behavior (De Groot \& Steg, 2007). This is a typical limitation of the theory of planned behavior. Secondly, our conclusions are based on cross-sectional data and thus our model represents only a snapshot of the actual situation. In future research, we should expand our present model by using a longitudinal study to investigate students' entrepreneurial intentions during different time periods, thus allowing us to make comparisons and provide greater insight into the phenomenon. Lastly, there could be cultural and national limitations to these findings due to cultural differences such as personal values, personal skills. This issue requires 
further investigation; it will be helpful to replicate this study on a wider scale with different national cultures in order to diversify the findings.

\section{References}

Abu-Saifan, S. (2012). Social entrepreneurship: definition and boundaries. Technology Innovation Management Review, 2(2).

Ajzen, I. (1985). From intentions to actions: A theory of planned behavior. In Action control (pp. 11-39). Springer Berlin Heidelberg. https://doi.org/10.1007/978-3-642-69746-3_2

Ajzen, I. (1991). Organizational behavior and human decision process. The Theory of Planned Behavior, 50(2), 179-211.

Anderson, J. C., \& Gerbing, D. W. (1988). Structural equation modeling in practice: Areview and recommended two-step approach. Psychological bulletin, 103(3), 411. https://doi.org/10.1037/0033-2909.103.3.411

Aranha, E. A., Garcia, N. A. P., \& Dos Santos, P. H. (2017). Fostering Entrepreneurship, Creativity and Innovation in Cities. International Business Research, 10(4), 92. https://doi.org/10.5539/ibr.v10n4p92

Armitage, C. J., \& Conner, M. (2001). Efficacy of the theory of planned behaviour: A meta-analytic review. British journal of social psychology, 40(4), 471-499. https://doi.org/10.1348/014466601164939

Autio, E., \& Acs, Z. (2010). Intellectual property protection and the formation of entrepreneurial growth aspirations. Strategic Entrepreneurship Journal, 4(3), 234-251. https://doi.org/10.1002/sej.93

Azmat, F., \& Samaratunge, R. (2009). Responsible entrepreneurship in developing countries: Understanding the realities and complexities. Journal of Business Ethics, 90(3), 437-452. https://doi.org/10.1007/s10551-009-0054-8

Bagozzi, R. P., \& Kimmel, S. K. (1995). A comparison of leading theories for the prediction of goal-directed behaviours. British Journal of Social Psychology, 34(4), 437-461. https://doi.org/10.1111/j.2044-8309.1995.tb01076.x

Bagozzi, R. P., Yi, Y., \& Phillips, L. W. (1991). Assessing construct validity in organizational research. Administrative science quarterly, 421-458. https://doi.org/10.2307/2393203

Bandura, A. (1986). The explanatory and predictive scope of self-efficacy theory. Journal of social and clinical psychology, 4(3), 359-373. https://doi.org/10.1521/jscp.1986.4.3.359

Baruch, Y. (2004). Transforming careers: from linear to multidirectional career paths: organizational and individual perspectives. Career development international, 9(1), 58-73. https://doi.org/10.1108/13620430410518147

Baum, J. R., Frese, M., \& Baron, R. A. (2014). The psychology of entrepreneurship. Psychology Press.

Bland, J. M., \& Altman, D. G. (1997). Statistics notes: Cronbach's alpha. Bmj, 314(7080), 572. https://doi.org/10.1136/bmj.314.7080.572

Brown, T. A. (2015). Confirmatory factor analysisfor applied research. Guilford Publications.

Bruyat, C., \& Julien, P. A. (2001). Defining the field of research in entrepreneurship. Journal of business venturing, 16(2), 165-180. https://doi.org/10.1016/S0883-9026(99)00043-9

Byrd, D. E. T. (2000). Measuring the flexibility of information technology infrastructure: Exploratory analysis of construct. Journal of Management Information Systems, 17(1), 167-208.

Byrne B. M. (2013). Structural equation modeling with AMOS: Basic concepts, applications, and programming. Routledge.

Caiden, G. E., Dwivedi, O. P., \& Jabbra, J. G. (2001). Where corruption lives (p.19). Bloomfield, CT: Kumarian Press.

Caldarelli, A., Ferri, L., \& Maffei, M. (2016). Expected benefits and perceived risks of cloud computing: an investigation within an Italian setting. Technology Analysis and Strategic Management, 1-14.

Carmignani, F. (2005). Efficiency of institutions, political stability and income dynamics. Public Economics, 503007.

Chwastiak, M. (2013). Profiting from destruction: The Iraq reconstruction, auditing and the management of fraud. Critical Perspectives on Accounting, 24(1), 32-43. https://doi.org/10.1016/j.cpa.2011.11.009 
Cohen, J., Krishnamoorthy, G., \& Wright, A. (2010). Corporate governance in the post-Sarbanes-Oxley era: Auditors' experiences. Contemporary Accounting Research, 27(3), 751-786. https://doi.org/10.1111/j.1911-3846.2010.01026.x

Covin, J. G., \& Slevin, D. P. (1991). A conceptual model of entrepreneurship as firm behavior. Entrepreneurship: Critical perspectives on business and management, 3, 5-28.

D’Onza, G., Brotini, F., \& Zarone, V. (2016). Disclosure on Measures to Prevent Corruption Risks: A Study of Italian Local Governments. International Journal of Public Administration, 1-13.

Davidsson, P. (1995). Culture, structure and regional levels of entrepreneurship. Entrepreneurship and Regional Development, 7(1), 41-62. https://doi.org/10.1080/08985629500000003

De Groot, J. I., \& Steg, L. (2007). Value orientations and environmental beliefs in five countries validity of an instrument to measure egoistic, altruistic and biospheric value orientations. Journal of Cross-Cultural Psychology, 38(3), 318-332. https://doi.org/10.1177/0022022107300278

Di Paola, N., Spanò, R., Vona, R., \& Caldarelli, A. (2016). Why Do Life Scientists Decide to Become Entrepreneurs? The Role of Motivations. International Journal of Business and Management, 11(5), 57. https://doi.org/10.5539/ijbm.v11n5p57

Douglas, E. J., \& Shepherd, D. A. (2002). Self-employment as a career choice: Attitudes, entrepreneurial intentions, and utility maximization. Entrepreneurship theory and practice, 26(3), 81-90.

Dutton, J. E., \& Ashford, S. J. (1993). Selling issues to top management. Academy of management review, 18(3), 397-428.

Dyer, W. G. (1994). Potential contributions of organizational behavior to the study of family-owned businesses. Family Business Review, 7(2), 109-131. https://doi.org/10.1111/j.1741-6248.1994.00109.x

Estrin S., Meyer K., \& Bytchkova M. (2013). 'Entrepreneurship in transition economies', in M. Casson et al. (eds), Oxford Handbook of Entrepreneurship, Oxford University Press, Oxford, 2006. Also see S. Estrin, J. A. Korosteleva, and T. Mickiewicz, 'Which institutions encourage entrepreneurial growth aspirations?', Journal of Business Venturing, 28(4), 564-580. https://doi.org/10.1016/j.jbusvent.2012.05.001

Estrin, S., Korosteleva, J., \& Mickiewicz, T. (2013). Which institutions encourage entrepreneurial growth aspirations? Journal of business venturing, 28(4), 564-580.

Everett, J., Neu, D., \& Rahaman, A. S. (2007). Accounting and the global fight against corruption. Accounting, Organizations and Society, 32(6), 513-542. https://doi.org/10.1016/j.aos.2006.07.002

Fatoki, O. O. (2010). Graduate entrepreneurial intention in South Africa: motivations and obstacles. International Journal of Business and Management, 5(9), 87-98.

Fayolle, A., \& Liñán, F. (2014). The future of research on entrepreneurial intentions. Journal of Business Research, 67(5), 663-666. https://doi.org/10.1016/j.jbusres.2013.11.024

Fjeldstad, O. H., \& Tungodden, B. (2003). Fiscal corruption: A vice or a virtue? World Development, 31(8), 1459-1467. https://doi.org/10.1016/S0305-750X(03)00089-5

Gangwar, H., Date, H., \& Raoot, A. (2014), Review on IT adoption: insights from recent technologies, Journal of Enterprise Information Management, 27(4), 488-502. https://doi.org/10.1108/JEIM-08-2012-0047

Gartner, W. B. (1990). What are we talking about when we talk about entrepreneurship? Journal of Business venturing, 5(1), 15-28. https://doi.org/10.1016/0883-9026(90)90023-M

Gibb, A. (2002). In pursuit of a new 'enterprise'and 'entrepreneurship'paradigm for learning: creative destruction, new values, new ways of doing things and new combinations of knowledge. International Journal of Management Reviews, 4(3), 233-269. https://doi.org/10.1111/1468-2370.00086

Glynn, P. S. J., \& Korbrin, M. N. (1997). The globalization of corruption. In K. A. Elliott, ed., Corruption and the Global Economy, 7-27, Institute for International Economics, Washington DC.

Gozukara, I., \& Colakoglu, N. (2016). Enhancing Entrepreneurial Intention and Innovativeness of University Students: The Mediating Role of Entrepreneurial Alertness. International Business Research,9(2), 34. https://doi.org/10.5539/ibr.v9n2p34

Griffiths, M. D., Kickul, J., \& Carsrud, A. L. (2009). Government bureaucracy, transactional impediments, and entrepreneurial intentions. International Small Business Journal, 27(5), 626-645. https://doi.org/10.1177/0266242609338752 
Gupta, S., Davoodi, H., \& Alonso-Terme, R. (2002). Does corruption affect income inequality and poverty?. Economics of governance, 3(1), 23-45. https://doi.org/10.1007/s101010100039

Hair, J. F., Black, W. C., Babin, B. J., Anderson, R. E., \& Tatham, R. L. (1998). Multivariate data analysis . Uppersaddle River. Multivariate Data Analysis (5th ed) Upper Saddle River.

Hall, C. (2002). Entrepreneurship Densities in APEC and Europe: How many entrepreneurs should there be in China, or other developing economies? Small Enterprise Research,10(1), 3-14. https://doi.org/10.5172/ser.10.1.3

Hamir, M. A. (1999). 'Keynote Address', in K. Frimpong and G. Jacques (eds.), Corruption, Democracy and Good Governance in Africa: Essays on Accountability and Ethical Behaviour (Lentswe La Lesedi, Gaborone, Botswana), pp. 1-8.

Harackiewicz, J. M., Barron, K. E., Tauer, J. M., \& Elliot, A. J. (2002). Predicting success in college: A longitudinal study of achievement goals and ability measures as predictors of interest and performance from freshman year through graduation. Journal of Educational Psychology,94(3), 562. https://doi.org/10.1037/0022-0663.94.3.562

Harris, M. L., \& Gibson, S. G. (2008). Examining the entrepreneurial attitudes of US business students. Education+ Training, 50(7), 568-581. https://doi.org/10.1108/00400910810909036

Hatten, T. S., \& Ruhland, S. K. (1995). Student attitude toward entrepreneurship as affected by participation in an SBI program. Journal of Education for Business, 70(4), 224-227. https://doi.org/10.1080/08832323.1995.10117754

Henderson, R., \& Robertson, M. (1999). Who wants to be an entrepreneur? Young adult attitudes to entrepreneurship as a career. Education+ Training, 41(5), 236-245. https://doi.org/10.1108/00400919910279973

Henry, C., Hill, F., \& Leitch, C. (2005). Entrepreneurship education and training: can entrepreneurship be taught? Part I. Education+ Training, 47(2), 98-111. https://doi.org/10.1108/00400910510586524

Henseler, J., Ringle, C. M., \& Sarstedt, M. (2015). A new criterion for assessing discriminant validity in variance-based structural equation modeling. Journal of the Academy of Marketing Science, 43(1), 115-135. https://doi.org/10.1007/s11747-014-0403-8

Hosmer Jr, D. W., Lemeshow, S., \& Sturdivant, R. X. (2013). Applied logistic regression (Vol. 398). John Wiley and Sons. https://doi.org/10.1002/9781118548387

Hu, L. T., \& Bentler, P. M. (1995). Evaluating model fit.

Hu, L. T., \& Bentler, P. M. (1998). Fit indices in covariance structure modeling: Sensitivity to underparameterized model misspecification. Psychologicalmethods, 3(4), 424. https://doi.org/10.1037/1082-989X.3.4.424

Hu, L. T., \& Bentler, P. M. (1999). Cutoff criteria for fit indexes in covariance structure analysis: Conventional criteria versus new alternatives. Structural equation modeling: a multidisciplinary journal, 6(1), 1-55. https://doi.org/10.1080/10705519909540118

Hussain, J. G., Scott, J. M., \& Hannon, P. D. (2008). The new generation: characteristics and motivations of BME graduate entrepreneurs. Education+ Training, 50(7), 582-596. https://doi.org/10.1108/00400910810909045

Kaiser, H. F. (1970). A second generation little jiffy. Psychometrika, 35(4), 401-415. https://doi.org/10.1007/BF02291817

Kaufmann, D., Kraay, A., and Mastruzzi, M. (2006). Measuring corruption: myths and realities. Development outreach, 8(2), 124-137.

Kautonen, T., Gelderen, M., \& Fink, M. (2015). Robustness of the theory of planned behavior in predicting entrepreneurial intentions and actions. Entrepreneurship Theory and Practice,39(3), 655-674. https://doi.org/10.1111/etap.12056

Kautonen, T., Tornikoski, E. T., \& Kibler, E. (2011). Entrepreneurial intentions in the third age: the impact of perceived age norms. Small business economics, 37(2), 219-234. https://doi.org/10.1007/s11187-009-9238-y

Kolvereid, L., \& Isaksen, E. (2006). New business start-up and subsequent entry into self-employment. Journal 
of Business Venturing, 21(6), 866-885. https://doi.org/10.1016/j.jbusvent.2005.06.008

Krueger, N. F., \& Brazeal, D. V. (1994). Entrepreneurial potential and potential entrepreneurs. Entrepreneurship theory and practice, 18,91-91.

Krueger, N. F., Reilly, M. D., \& Carsrud, A. L. (2000). Competing models of entrepreneurial intentions. Journal of business venturing, 15(5), 411-432. https://doi.org/10.1016/S0883-9026(98)00033-0

Krueger, N., \& Dickson, P. R. (1994). How believing in ourselves increases risk taking: Perceived self-efficacy and opportunity recognition. Decision Sciences, 25(3), 385-400.

https://doi.org/10.1111/j.1540-5915.1994.tb01849.x

Kuratko, D. F. (2005). The emergence of entrepreneurship education: Development, trends, and challenges. Entrepreneurship theory and practice, 29(5), 577-598. https://doi.org/10.1111/j.1540-6520.2005.00099.x

Lambsdorff, J. G. (2003). How corruption affects productivity. Kyklos, 56(4), 457-474. https://doi.org/10.1046/j.0023-5962.2003.00233.x

Li, M., \& Bray, M. (2007). Cross-border flows of students for higher education: Push-pull factors and motivations of mainland Chinese students in Hong Kong and Macau. Higher Education, 53(6), 791-818. https://doi.org/10.1007/s10734-005-5423-3

Liñán, F., \& Chen, Y. W. (2009). Development and Cross-Cultural application of a specific instrument to measure entrepreneurial intentions. Entrepreneurship theory and practice,33(3), 593-617. https://doi.org/10.1111/j.1540-6520.2009.00318.x

Lund, K. (2016). Facilitating corporate entrepreneurial behavior: A study of corporate entrepreneurial behavior in corporate banking.

Martin, R. L., \& Osberg, S. (2007). Social entrepreneurship: The case for definition. Stanford social innovation review, 5(2), 28-39.

Matlay, H. (2006). Researching entrepreneurship and education: Part 2: what is entrepreneurship education and does it matter? Education + Training, 48(8/9), 704-718. https://doi.org/10.1108/00400910610710119

McDonald, R. P. (1981). The dimensionality of tests and items. British Journal of mathematical and statistical Psychology, 34(1), 100-117. https://doi.org/10.1111/j.2044-8317.1981.tb00621.x

Melgar, N., Rossi, M., \& Smith, T. W. (2010). The perception of corruption in a cross-country perspective: why are some individuals more perceptive than others? Economia Aplicada, 14(2), 183-198. https://doi.org/10.1590/S1413-80502010000200004

Min, H., \& Galle W. P. (2003). E-purchasing: profiles of adopters and nonadopters. Industrial Marketing Management, 32(3), 227-233. https://doi.org/10.1016/S0019-8501(02)00266-3

Minniti, M., \& Bygrave, W. (2003). Global entrepreneurship monitor: national entrepreneurship assessment. United States of America.

Mitchell, R. K., Busenitz, L. W., Bird, B., Marie Gaglio, C., McMullen, J. S., Morse, E. A., \& Smith, J. B. (2007). The central question in entrepreneurial cognition research 2007. Entrepreneurship Theory and Practice, 31(1), 1-27.https://doi.org/10.1111/j.1540-6520.2007.00161.x

Montano, D. E., \& Kasprzyk, D. (2015). Theory of reasoned action, theory of planned behavior, and the integrated behavioral model. Health behavior: Theory, research and practice.

Omorede, A., Thorgren, S., \& Wincent, J. (2015). Entrepreneurship psychology: a review. International Entrepreneurship and Management Journal, 11(4), 743-768. https://doi.org/10.1007/s11365-014-0307-6

Otusanya, O. J. (2011). The role of multinational companies in tax evasion and tax avoidance: The case of Nigeria. Critical Perspectives on Accounting, 22(3), 316-332. https://doi.org/10.1016/j.cpa.2010.10.005

Phan, P. H., Wong, P. K., \& Wang, C. K. (2002). Antecedents to entrepreneurship among uni versity students in Singapore: beliefs, attitudes and background. Journal of Enterprising Culture, 10(02), 151-174. https://doi.org/10.1142/S0218495802000189

Politis, D. (2005). The process of entrepreneurial learning: A conceptual framework. Entrepreneurship theory and practice, 29(4), 399-424. https://doi.org/10.1111/j.1540-6520.2005.00091.x

Quazi, R., Vemuri, V., \& Soliman, M. (2014). Impact of corruption on foreign direct investment in 
Africa. International Business Research, 7(4), 1-10. https://doi.org/10.5539/ibr.v7n4p1

Radin, T. J., \& Calkins, M. (2006). The struggle against sweatshops: Moving toward responsible global business. Journal of Business Ethics, 66(2), 261-272. https://doi.org/10.1007/s10551-005-5597-8

Robinson, P. B., Stimpson, D. V., Huefner, J. C., \& Hunt, H. K. (1991). An attitude approach to the prediction of entrepreneurship. Entrepreneurship theory and practice, 15(4), 13-31.

Sevüktekin, M., Nargeleçekenler, M., \& Giray, F. (2010). A cross-country comparison of corruption and public expenditures: A panel data approach. International Journal of Public Administration,33(3), 140-150. https://doi.org/10.1080/01900690903304159

Shapero, A., \& Sokol, L. (1982). The social dimensions of entrepreneurship.

Shaver, K. G. (1987). Principles of social psychology (3rd ed.). Cambridge: Winthrop.

Shin, H. (2015). The Relationship between the Arab Spring Revolutions and Entrepreneurial Inhibitors, Enablers, and Activity in North Africa. Comparative Case Studies on Entrepreneurship in Developed and Developing Countries, 82-98. https://doi.org/10.4018/978-1-4666-7533-9.ch005

Shook, C. L., \& Bratianu, C. (2010). Entrepreneurial intent in a transitional economy: an application of the theory of planned behavior to Romanian students. International Entrepreneurship and Management Journal, 6(3), 231-247. https://doi.org/10.1007/s11365-008-0091-2

Spanò, R. Ferri, L., Fiondella, C., \& Maffei M., (2017). Accountability and Reporting in the Fight against Corruption: Preliminary Evidences from the Italian Setting. International Journal of Business and Management, 12(4), 1-9. https://doi.org/10.5539/ijbm.v12n4p1

Spanò, R., Paola, N. D., Caldarelli, A., \& Vona, R. (2016). Accountants' hybridization and juridification: a critical reflection on the fight against organized crime. Public Money \& Management, 36(6), 441-446. https://doi.org/10.1080/09540962.2016.1190208

Stapenhurst, R., \& Sedigh, S. (1999). Introduction: An Overview of the Costs of Corruption and Strategies to Deal with It. Curbing Corruption: Toward a model for building national integrity". Washington DC: The World Bank.

Strecher, V. J., Devellis, B. M., Becker, M. H., \& Rosenstock, I. M. (1986). The role of self-efficacy in achieving health behaviour change, Health Educ. In Behav.

Stuetzer, M., Obschonka, M., Davidsson, P., \& Schmitt-Rodermund, E. (2013). Where do entrepreneurial skills come from? Applied Economics Letters, 20(12), 1183-1186. https://doi.org/10.1080/13504851.2013.797554

Sullivan, R. (2000). Entrepreneurial learning and mentoring. International Journal of Entrepreneurial Behavior and Research, 6(3), 160-175. https://doi.org/10.1108/13552550010346587

Turker, D., \& Selcuk, S. S. (2009). Which factors affect entrepreneurial intention of university students? Journal of European Industrial Training, 33(2), 142-159. https://doi.org/10.1108/03090590910939049

Van Gelderen, M., Brand, M., van Praag, M., Bodewes, W., Poutsma, E., \& Van Gils, A. (2008). Explaining entrepreneurial intentions by means of the theory of planned behaviour. Career Development International, 13(6), 538-559. https://doi.org/10.1108/13620430810901688

Zhao, H., \& Seibert, S. E. (2006). The big five personality dimensions and entrepreneurial status: a meta-analytical review.

Zhao, H., Seibert, S. E., \& Hills, G. E. (2005). The mediating role of self-efficacy in the development of entrepreneurial intentions. Journal of applied psychology, 90(6), 1265. https://doi.org/10.1037/0021-9010.90.6.1265

\section{Copyrights}

Copyright for this article is retained by the author(s), with first publication rights granted to the journal.

This is an open-access article distributed under the terms and conditions of the Creative Commons Attribution license (http://creativecommons.org/licenses/by/4.0/). 